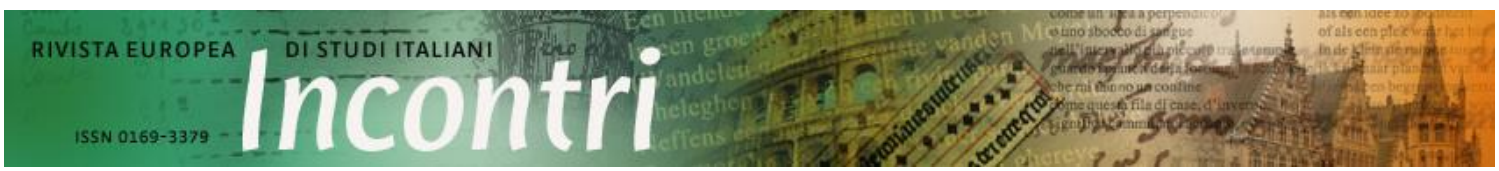

Anno 35, 2020 / Fascicolo 1 / p. 99-115 - unw.rivista-incontri.nl - http://doi.org/10.18352/incontri.10337

(c) The author(s) - Content is licensed under a Creative Commons Attribution 3.0 Unported License Publisher: Werkgroep Italië Studies, supported by Utrecht University Library Open Access Journals

\title{
Eco-Pusterla
}

\section{A semantic-stylistic analysis of Bocksten}

\author{
Alice Loda
}

\author{
Adesso sì, sorella, e più di prima, \\ se guizzi disperata tra scoli d'atrazina \\ e getti d'olio vischioso; \\ o se colpisci di coda, estenuata, \\ la carezza dell'onda di fosfati che s'annera \\ sulla ghiaia della riva $[. . .]^{1}$
}

When Fabio Pusterla depicts the eel of the Rhine - a more-than-human sibling who struggles to snatch a breath while moving through the polluted waters of the river, in the aftermath of the Schweizerhalle environmental tragedy - he is indeed speaking about himself, and humanity as a whole. The path that the poet had undertaken in Bocksten, and which culminates in this poem, had brought him to the conclusion that what remains for human and more-than-human crowds alike is a glimpse, an intuition of the presence and smell of the sea, a memory of freedom, which is equal for all the creatures on earth.

This powerful image from Bocksten, one of the masterpieces of contemporary italophone ecopoetry, allows me to introduce the main theme of this study: that of the progressive development of an ecocentric and ecological voice within contemporary poetics, and of its embodiment in the verse of one of the most prominent italophone voices. Although the primary sources analysed are exclusively in Italian, the italophone tradition will not act as a rigid and impassable critical barrier in the ensuing explorations. On the contrary, ecopoetry is read as a phenomenon based in a constitutive translocal and translingual interconnectedness, and as a trajectory profoundly shaped by relational dynamics, which are primary actors in the present literary, cultural, and material space. ${ }^{2}$

\footnotetext{
${ }^{1}$ L'anguilla del Reno, in: F. Pusterla, Bocksten, Milan, Marcos y Marcos, 2003, p. 85. All excerpts presented herein are from this edition. Individual poems are identified with a progressive number following the order of their appearance in the book, accompanied by the indication of line numbers if only a portion of text is quoted.

Acknowledgments: This article is part of a project on Italophone ecopoetics which was funded by the University of Technology of Sydney, School of International Studies Seeding Grants in 2018. I would like to thank Dr Emma Barlow who worked at the project as a Research Assistant and Associate Prof. Ilaria Vanni who provided extensive feedback on a first version of the article.

2 For the notion of translocality see S. Slovic, 'Translocalità. La nozione di luogo nell'ecocritica contemporanea', in: C. Salabè (ed.), Ecocritica. La letteratura e la crisi del pianeta, Rome, Donzelli, 2013, pp. 27-42. In this chapter, Slovic defines translocality as a notion that encompasses the specificity of places and the trajectories that connect them to other places. It is within this nuance that the notion is employed herein.
} 
My investigation opens with a section that builds the framework and constitutes a foundation for the ensuing textual analysis. This critical discourse, which covers various recent scholarly trajectories in ecopoetics and ecocriticism, is then allowed to interact with three key-concepts tailored to my case study: receptivity, intertextuality, and translation. These concepts foreground Pusterla's work in fundamental ways, and - most crucially for this discourse - have a significant impact on the agglomeration and progression of an ecological intention in his poetry.

As I explain below, the concepts of receptivity, intertextuality, and translation are related to Pusterla's renowned attitude towards deep listening and reading, qualities that have moulded the author's poetic performance since its beginnings. Pusterla is, in fact, a philologist (trained at the University of Pavia, one of the most rigorous philological schools in Italy), as well as a literary translator from French. Both these aspects are inextricably connected to his poetic practice in a way that, I argue, deserves critical attention beyond the examination of individual textual influences, and requires assessment on a systemic level. In fact, whilst the acts of reading and listening are always constitutive of poetic practice, the relational quality of Pusterla's versification is somewhat accelerated. In the following paragraphs, I connect this receptive attitude to the ecocentric nature of Pusterla's work, while ecocritical frameworks provide a basis for the analysis of implications on a more comprehensive ground.

In a second part, this study moves from the theoretical context to the verse itself, presenting a close reading of the poetry collection Bocksten, one of Pusterla's early works, first published by Marcos y Marcos in 1989 and then re-issued by the same publisher in 2003 without substantial variants. Bocksten is not the only book, amongst Pusterla's writings, to foreground an environmental path. In fact, ecocentric trajectories are significantly explored, developed, and strengthened by the author in ensuing works, and they inform more generally the poet's main epistemological research. Bocksten represents, however, a critical step in the unfolding of Pusterla's ecopoetic discourse, mostly because it chooses to focus on one crucial liminal character, a fossil-man, who translates within his own transformative and relational body the constitutive mutual embeddedness of human and non-human as well as the foundational interconnectedness that characterises the environment. An analysis that wishes to reframe Pusterla's works within the theoretical realm of ecopoetry, needs, as such, to engage first and foremost with this early and fundamental juncture.

The analysis of Bocksten is oriented towards rhythmical and figurative aspects. Rhythm is here conceived, in Meschonnic's terms, as the main carrier of meaning in a poetic discourse, the historicisation of a subject in a language-history. ${ }^{3}$ As such, particularly in the wake of recent crucial studies in ecopoetics, it is regarded as one of the pillars of Pusterla's ecopoetic performance. ${ }^{4}$ The rhythmical analysis expands on polyphony, in order to let emerge the ways in which dialogic structures facilitate a decentring of subjectivity. This process supports the poet in illuminating outwardsfacing interconnected realities over inwards-facing ones, following a trajectory that Susanna Lidström and Greg Garrard have defined as 'ecophenomenological'. ${ }^{5}$ An ecophenomenological poetic mode is characterised first of all by an ability to observe, listen, and give voice to what is outside of the individual subject, attributes which are consistently at the centre of Pusterla's research.

\footnotetext{
${ }^{3}$ H. Meschonnic, Pour la poétique II, Paris, Gallimard, 1963.

${ }^{4}$ See C. Scott, 'Translating the nineteenth century: a poetics of eco-translation', in: Dix-Neuf, 19, 3 (2015), pp. 285-302.

5 S. Lidström \& G. Garrard, “"Images adequate to our predicament”: ecology, environment and ecopoetics', in: Environmental Humanities, 5, 1 (2014), p. 37.
} 
This study also expands on the figurative level, and highlights the progressive clustering of what I define as transitional imagery in Bocksten. Transitional imagery refers to poetic embodiments of crossings and transformations, such as portrayals of interspecies transitions, and intersections between different elements and matters. This section demonstrates that the transitional imagery, and in particular the personifications, scaffold in Pusterla's work a fluid and dialogic understanding of the human, conceived of 'not as an atomistic individual engaged in the world as a resource for consumption and self-assertion, but as part of a greater living identity' ${ }^{6}$ The frequency and centrality of transitional imagery also indicates the growth of an 'environmental' stream in Pusterla's poetry. Lidström and Garrard consider environmental poetry as an aesthetic discourse permeated by a relational idea of the world, wherein the social and natural systems, including language and nature, are considered to be intertwined. These systems are conceptualised as constantly codeterminising and co-generating realities, as opposed to a conventional essentialised and binary understanding. ${ }^{7}$

After expanding on all the above trajectories, this article closes with a paragraph that summarises the results of the analysis, signals possible ways forward, and restates the centrality of poetry, within the present environmental and ecocritical discourse, in reimagining the world as a more equitable, interconnected, and inclusive space.

\section{Ecopoetry}

The analysis of Pusterla's environmental and ecocentric progression allows us an insight into the capsizing of perspective that has occurred, within and beyond italophone poetics, towards the end of the last millennium and in the first two decades of the current. A dynamics of dismantling of monological subjectivities was already and notoriously in action in European poetry from at least the second half of the twentieth century, and led to many postmodern diffractions, while authorial attention progressively shifted from subject to objects. ${ }^{8}$ In the dominant aesthetic discourse, however, the non-human (and the objects within it) functioned primarily as the correlative objective of the human; that is, as a tool for enquiring about the nature of human emotions or the human's status and positioning. ${ }^{9}$ The epistemological question maintained overall an anthropocentric direction, and a deep ecological discourse was still not at the forefront of most influential poetics.

Between the last two decades of the past century and the present time, poetic expression underwent a significant mutation, recording the emergence of many deeply relational poetics, characterised on the whole by a more radical decentring of the human and a repositioning of its experience within an interconnected environment. Many scholars have explored this transition (or a part of it) within italophone poetics, tracing a number of expressions that arose post-Montale as the point of departure for an aesthetic turn. As will be seen, however, this turn has been described in diverse terms and mostly outside of ecocritical frameworks. Maria Antonietta Grignani, for instance, has individuated a series of common traits within what she calls the italophone poetics of 'the end of the millennium', traits that I identify as ecocentric: an inclination towards a self-reduction of the lyric subject, a focus on objects, and, most crucially, an understanding of language as 'mezzo imperfetto di un perpetuo

\footnotetext{
6 T. Clark, The Cambridge introduction to literature and the environment, New York, Cambridge University Press, 2011, p. 2, quoted in Lidström \& Garrard, “"Images adequate to our predicament”, cit., p. 38.

7 Ivi, pp. 44-46.

${ }^{8}$ See for instance M. Cavadini, Il poeta ammutolito. Letteratura senza io: un aspetto della postmodernità poetica: Philippe Jaccottet e Fabio Pusterla, Milan, Marcos y Marcos, 2004.

${ }^{9}$ See G. Belletti, 'Cosa perde l'io: ie istituzioni letterarie e la poesia di Fabio Pusterla', in: Poetiche, 11, 1 (2009), pp. 144-145.
} 
desiderio di approssimazione all'altro da sé'. ${ }^{10}$ According to Grignani, Pusterla is one of the main protagonists of this turn.

Other critical categories have been advanced to describe this recent shift. Fabio Moliterni, for instance, has argued for the progressive growth within the italophone scene of a 'poetics of attention', which in his view is particularly visible in a series of works published over the past three decades, including some of Pusterla's books. ${ }^{11}$ According to Moliterni, these poetics make a sharp turn towards attenzione, a critical notion that points to receptivity as a foundational quality. Moliterni indicates polyphony, dialogism, metapoetic reflection, loss of metaphysical tensions, lyric use of everyday objects, and crossings from the individual to the collective as some of the common traits of these poetics. As we shall see, all of these characteristics thoroughly permeate Pusterla's poetry, and foreground his ecocentric path.

On the whole, ecology provides a framework through which to read these features - and thus the aforementioned authorial turn - as a systemic trajectory, which is active translocally and well beyond the italophone field. Grignani suggests some transnational paths and connects this turn to the dramatic increase in communications and contacts which led, towards the end of the millennium, to an unprecedented circulation of information and consequently of environmental awareness. ${ }^{12}$ Moreover, the worsening of living conditions for all life on the planet pushed the authors of this generation to confront the damage caused and the dangers posed by humans, as such to reflect on responsibilities towards a shared interconnected ecosystems. If literary expression can be conceptualised as a "sensorium" of historical processes - both social and ecological', ${ }^{13}$ then it is clear that the trajectory of a consistent part of the present poesia civile, in a time of unprecedented environmental crisis, revolves around an anti-anthropocentric mission, and aims to illuminate dynamics of co-existing and co-becoming within the environment as key processes for understanding the world.

In this study, I reframe all these trajectories within the realm of ecopoetry. But what is ecopoetry? An effective synthesis of various definitions is provided by J. Scott Bryson. ${ }^{14}$ Despite the array of nuances, the scholarly discussion summarised by Bryson individuates a series of common features in environmentally-oriented and ecological literatures, which includes the focus on relation, interrelation, and feedback, the presence of the non-human as more than a background, and the insistence on human accountability in the face of the crisis. ${ }^{15}$ Bryson himself, building on previous scholarship, elaborates a definition that points to a continuity between ecopoetry and traditional nature poetry:

Ecopoetry is a mode that, while adhering to certain conventions of traditional nature poetry, advances beyond that tradition and takes on distinctively contemporary problems and issues. ${ }^{16}$

Bryson then goes on to individuate three characteristics that are foundational to contemporary ecopoetry: the presence of an ecological and biocentric perspective that is able to acknowledge the interdependent nature of the world; an anti-hierarchical

\footnotetext{
${ }^{10}$ M.A. Grignani, Lavori in corso: poesia, poetiche, metodi nel secondo Novecento, Modena, Mucchi, 2007, p. 129.

${ }^{11} \mathrm{~F}$. Moliterni, 'La nuova poesia dell'attenzione. Su alcuni poeti italiani contemporanei', in: The Italianist, 26, 1 (2006), pp. 114-154.

12 Grignani, Lavori in corso, cit., p. 121.

13 S. lovino, 'Sedimenting stories: Italo Calvino and the extraordinary strata of the Anthropocene', in: Neohelicon, 44, 2 (2017), p. 316.

14 J.S. Bryson, The west side of any mountain: place, space, and ecopoetry, lowa City, University of lowa Press, 2005.

15 Ivi, pp. 1-2

16 Ivi, p. 2.
} 
disposition in exploring human-non-human relationships; and a scepticism towards the hyperrationality of an over-technologised world. With the first two factors being highly prominent (and the third being present if in a more implicit way), Pusterla's poetry is easily located within this translocal ecopoetic horizon.

While taking into account these seminal readings, this study aims to engage fluidly with the notion of ecopoetics, considering it to be an intersection of authorial dispositions (typical of the ecocritical turn mentioned above) and interpretative tools (that is, a way to analyse texts in their relational, trans-subjective, and most importantly more-than-human qualities). The latter is a critical operation that has led to the reassessment of many pre-modern and modern poetics, revealing more about the evolution of ecocentric thought across the centuries. ${ }^{17}$ Particularly effective, for instance, has been the recent ecocritical exploration of the works of Giacomo Leopardi, an author that I consider the main precursor of many contemporary materialist and environmental poetics, and a significant influence on Pusterla. ${ }^{18}$

Tracing ample diachronic trajectories within the realm of ecopoetics is thus not only possible, but also extremely productive. Yet the authors of Pusterla's generation maintain a distinctiveness of gaze that needs to be acknowledged. Textually, this is reflected in the radical amplification of relational and trans-subjective features, which are impacted in these works by increased environmental awareness and direct observation of an unprecedented crisis. When exploring the ecocritical qualities of Italo Calvino's narrative works, Serenella lovino spoke about Calvino's intuition regarding the irreversible consequences of the 'great acceleration', a phase of unprecedented 'growth' and environmental exploitation that was happening before the author's very eyes while he was compiling his narrative works. ${ }^{19}$ The devastating effects of this acceleration - which in Italy meant reckless construction, including in zones with high hydrogeological instabilities, as well as water, soil, and air pollution, as counterparts to rapid and poorly-planned industrial development - is mostly sedimented in the author's imagery as the intuition of a future catastrophe. This intuition led to the formation of a number of ecocentric concentrations in Calvino's work, including a focus on human-non-human interconnections, that prefigure the present ecocritical turn. What differentiates authors like Calvino from authors like Pusterla in environmental terms, however, is that while for the former the crisis is still primarily a perception, a presentiment, for the latter it is a reality to be observed and acknowledged every day. It is thus the intensity of the crisis that has dramatically changed in recent ecopoetics, wherein authors are increasingly presented with the urgent need to formulate individual and collective responses to that crisis.

Whilst ecopoetry provides a guiding point for the analysis, further critical notions may lend additional support to this brief contextualisation. The afore-mentioned concepts of 'ecophenomenological' and 'environmental' poetry, for instance, as introduced by Lidström and Garrard, provide two fundamental vectors for the framing of Pusterla's work. ${ }^{20}$ The first indicates a poetic mode that pursues an erasure of subjectivity in order to allow the outward reality to speak. The second points instead to a dismantling of ontological borders and conventional power dynamics between subject and alterity, society and nature, human and non-human, in works that embody interconnected and co-determining ecologies. Pusterla's verse moves continually across these two trajectories, with Bocksten acting as a fundamental point of

\footnotetext{
17 See for example N. Scaffai, Letteratura e ecologia: forme e temi di una relazione narrativa, Rome, Carocci, 2017.

${ }^{18}$ See the special issue edited by P. Ceccagnoli \& F. D’Intino: “"Eco-Leopardi”. Visioni apocalittiche e critica dell'umano nel poeta della Natura', in: Costellazioni, 10 (2019).

19 lovino, 'Sedimenting stories', cit., p. 316.

20 See notes 5 and 7 above.
} 
connection between them.

Material ecocriticism, and in particular the work of Serenella lovino and Serpil Opperman, provides the current analysis with the pivotal notion of 'storied matter', a notion that conveys the idea that stories and narratives are physically inscribed in matter itself. ${ }^{21}$ According to this conceptualisation, the land itself can tell a story, and can be read as a text:

Material ecocriticism heeds the stories inbuilt in matter - in all matter, from cells to ecosystems, from historic landscapes to gendered bodies and their social constructions. All of these material things are creatively expressive: They are 'storied matter' in which collectives of human and nonhuman actors intersect and whose existence is in mutual dependence and determination..$^{22}$

Pusterla's reader will immediately perceive the consonance between these words and his poetics, which since its beginning has pursued the unveiling of trans-subjective and trans-human stories embedded in the observed reality, and especially in its peripheries. In the following three sections I shall explore some of the trajectories and modes in which this process takes place.

\section{Receptivity}

With the term receptivity, I allude in this study to an authorial position which is based, first and foremost, on the ability to perform an insightful observation and listening of the outward reality and its constitutive balances. The notion of receptivity can be used as a fil rouge to traverse Pusterla's work and intellectual path. Born in the canton of Ticino, the italophone region of Switzerland, Pusterla grew up in Chiasso, a town sprawled directly at the border with Italy. This frontaliera position had a significant impact on his aesthetic research, which is foregrounded by a fluid conceptualisation of borders. ${ }^{23}$ Pusterla's intellectual itinerary developed across a territory extending from Ticino to nearby Lombardy. Articulated across two distinct countries, this territory is part of an ecoregion comprising a continuity of landscapes, languages, and colours that will come to distinguish the author's emplaced yet translocally-connected poetics. ${ }^{24}$ As John Charles Ryan points out, ecoregional frameworks - as opposed to 'national' human-oriented ones - offer the chance to formulate 'alternative ecocultural imaginaries and relational possibilities'. ${ }^{25}$ Hence, ecoregional thinking is a productive space in which to contextualise Pusterla's liminal and ecocentric poetics.

From the start, Pusterla's verse has stood out because of its focus on outwards realities and its attempts to let what is outside of the subject speak; that is, for its 'trans-individual' qualities. ${ }^{26}$ The poet himself explains in a interview: 'l'esistente, ossia ciò che esiste al di fuori di me, attorno a me, è forse il territorio che mi interessa maggiormente esplorare'. ${ }^{27}$ Landscapes, and especially mountain environments, with their catalogue of plants and creatures, participate in the verse's construction, which is foregrounded by increasing identification between form and nature. ${ }^{28}$ Within a poetry that consistently pursues symbiosis with nature and objects, Pusterla is

\footnotetext{
${ }^{21}$ S. lovino \& S. Oppermann, Material ecocriticism, Bloomington, Indiana University Press, 2014.

22 S. lovino, Ecocriticism and Italy: ecology, resistance, and liberation, London, Bloomsbury, 2017.

23 See F. Pusterla, 'L'Inferno è non essere gli altri. Scrittura poetica, traduzione e metamorfosi dell'io', in: Quaderns d'Italià, 7 (2002), pp. 23-29.

${ }^{24}$ For the significance of ecoregions in the contemporary ecocritical discourse see D.A. Finch-Race \& V. Gosetti, 'Discovering industrial-era francophone ecoregions', in: Dix-Neuf, 23, 3-4 (2019), pp. 151-162.

25 J.C. Ryan, 'Foreword: ecocriticism in the age of dislocation?', in: Dix-Neuf, 23, 3-4 (2019), p. 3.

26 Lidström \& Garrard, “"Images adequate to our predicament”', cit., p. 49.

27 T. Fratus, 'Pusterla, poesia è paesaggio', in: «ll manifesto», 6 June 2019.

28 On form and nature in poetry see D.A. Finch-Race \& J. Weber, 'The Ecocritical stakes of French poetry from the Industrial Era', in: Dix-Neuf, 23, 3-4 (2019), pp. 159-166.
} 
attracted by non-human actors that are conventionally considered peripheral including rocks, plants, insects, daily objects, and micro-organisms - whose qualities and hidden stories are revealed and placed at the centre of the scenes. The author himself expands on this point:

Credo di aver capito che a colpirmi, delle realtà che incontro, sono soprattutto due cose: la marginalità degli oggetti, cioè il loro apparire quasi casualmente ai margini del quadro d'assieme, mai al centro; e le connessioni impreviste che si possono stabilire fra di loro. ${ }^{29}$

The 'storied matter' is thus what attracts his gaze, while poetic language is used ecophenomenologically by the author to liberate objects and creatures from anthropocentric superstructures, and come closer to their material truth.

Scholars have pointed out that Pusterla's books of poetry, amongst which nine major publications stand out in particular, can be considered anti-canzonieri. ${ }^{30}$ In other words, they lack a cohesive narrative structure, and favour instead an aesthetics of fragmentation, which acts primarily as the mimesis of a disaggregated, fragile, and precarious observed reality. Broadening the perspective to embrace the whole of Pusterla's poetic path, we can argue that the focus on the fragment is the figurative counterpoint and the embodiment of the poet's attraction to the peripheral, and that receptivity may be considered the ideal frame or macrotext within which to examine his whole oeuvre. While slightly shadowed in the first collection, which was still permeated by a dominant rage and by expressionist deformations, receptive qualities - conceptualised as an ability to listen to, read, and transparently translate the stories of the matter - are magnified in Bocksten and are further refined in the ensuing collections.

This progression towards receptivity materialises over time along a specific aesthetic path, which involves the mobilisation of some of the conventional coordinates of poetic writing. The first component of this process engages with Pusterla's distinctive more-than-human treatment of time. As scholars have pointed out, the poet measures his experience - with increasing intensity - within a morethan-human geological time rather than a human-historical one. ${ }^{31}$ As such, representations of erosions, continent separations, rock formations, sedimentations, and fossilisations are particularly frequent, while human history is re-read within a more-than-human perspective. As it is for other poets such as Seamus Heaney, the function of recontextualising human history within a geological one is performed by a revenant, a fossil-man, whose trans-human nature facilitates an opening of the diachronic horizon.

A second component of the progression of receptivity relates to a gradual increase in sensual, onomatopoeic, polyphonic, and mimetic effects within the diction, in a system where syntax is a pivotal element. In this context, Andrea Afribo has pertinently spoken of a sintassi presentativa, a notion which points to the poet's desire to infuse his modules with transparency and clarity, and which as such encompasses his favouring of parataxis, lists, nominalisations, accumulations, and the overall use of plain diction, all elements that reinforce identification between form and nature. ${ }^{32}$ Moreover, Pusterla's treatment of syntax, especially when articulated in extended forms such as in the case of L'anguilla del Reno quoted above, has been read as an

\footnotetext{
${ }^{29}$ T. Fratus, 'Pusterla, poesia è paesaggio', cit.

30 A. Afribo, Poesia contemporanea dal 1980 a oggi. Storia linguistica italiana, Rome, Carocci, 2007, p. 23, cited in B. Manetti, 'Il «libro del figlio»: Bocksten di Fabio Pusterla', in: S. Stroppa (ed.), La poesia italiana degli anni ottanta. Esordi e conferme. II, Pensa Multimedia, Lecce, 2017, pp. 211-233.

31 See Manetti, 'Il “libro del figlio"', cit., p. 229.

32 Afribo, Poesia contemporanea dal 1980 a oggi, cit., p. 115.
} 
embodiment of 'resistance', a keyword that lovino has convincingly located into the realm of eco-literature, together with the concept of 'liberation' ${ }^{33}$ On the whole, this constitutive attention to receptivity both nourishes and is nourished by two further ecopoetic components that I shall briefly address below: intertextuality and translation.

\section{Intertextuality}

Many scholars have worked on intertextuality in Pusterla, tracing the influence of several authors in his diction, and especially of the poet laureate Eugenio Montale, one of his main interlocutors since the beginning of his poetic career. ${ }^{34}$ Here I will not enter into the discourse on textual coincidences, preferring instead to discuss how intertextuality acts as a system within Pusterla's verse, and contributes to the empowerment of its ecocentric qualities. Julia Kristeva notoriously conceived of intertextuality as a mingling of textual and socio-historical aspects, separating it from the concept of intersubjectivity, which points instead to ideological-emotional consonances between authors. ${ }^{35}$ Based on both textual evidence and Pusterla's own interventions, I argue that it is the first rather than the second aspect that is persistently active in his work and possesses a generative potential within ecopoetic frameworks. In fact, Pusterla's intertextuality does not act as a phenomenon of semantic transfer across allusion, nor as mere citationism or a declaration of ideological-emotional consonance. Rather, it serves as a reagent that allows the relational, hybrid, and trans-historical qualities of the written word to emerge. Pusterla himself refers to chemical reactions when called to unpack his intertextual relationship with Montale:

La poesia di Montale esiste per me soprattutto nella sua composizione chimica [...] una composizione chimica in cui, se dovessi identificare le molecole per me principali, sottolineerei soprattutto i suoni e le immagini. ${ }^{36}$

In his persuasive and well-documented essay on Pusterla's montalismo, Pietro Benzoni introduces two notions that I consider crucial to explaining the nature of Pusterla's relational and non-intersubjective use of intertextuality: metabolisation and propagation. ${ }^{37}$ Maintaining a focus on the intersubjective distance that the author retains in respect to his interlocutors - whose lectio is often deactivated, erased, or capsized in meaning and intention - I argue that Pusterla's sources are first of all metabolised and then used to amplify the receptive and trans-individual nature of his verse.

Intertextual inserts are mostly introduced out of a rhythmical exigency, and represent a further means of decentring the authorial voice. In Pusterla's work the dialogue with sources is thus configured as repetition via a critical distance, a persistent oscillation between belonging and detaching, and, most crucially, a process of pluralisation of the voice so pervasive that it has been defined as pulviscolare. ${ }^{38}$

\footnotetext{
${ }^{33}$ A De Marchi, 'L'anguilla di Montale e le sue sorelle. Sulla funzione poetica della sintassi', in: Testo, 26, 50 (2005); lovino, Ecocriticism and Italy, cit., pp. 5-8.

${ }^{34}$ See the detailed works by P. Benzoni: 'Le smorfie del ghiaccio che si sgretola. Il montalismo di Fabio Pusterla', in: Stilistica e Metrica Italiana, 5 (2005), pp. 267-310; 'Tre pastiches montaliani di Fabio Pusterla', in: Per Leggere, 7, 12 (2007), pp. 69-80.

35 J. Kristeva, 'Problèmes de la structuration du texte', in: Théorie d'ensemble, Paris, Éditions du Seuil, 1968, pp. 297-316; J. Kristeva, 'The bounded text', in: Desire in language: a semiotic approach to literature and art, New York, Columbia University Press, 1980, pp. 36-63.

${ }^{36}$ F. Pusterla, 'Dubbi più che altro', in: M.A. Grignani \& F. Luperini, Montale e il canone poetico del Novecento, Rome-Bari, Laterza, 1998, p. 435.

37 Benzoni, 'Le smorfie del ghiaccio che si sgretola', cit., pp. 267-269.

38 Benzoni, 'Tre pastiches montaliani di Fabio Pusterla', cit., p. 78.
} 
The practice is thus active from within the smallest components of versification.

A second keyword introduced by Benzoni is propagation. While it is true that sources are metabolised and then reconveyed through a transformative chemical reaction in Pusterla's poetry, it is also true that intertextual inserts retain a polisemantic and historical weight which the author fully acknowledges. These transindividual and trans-historical qualities are again used as agents to propagate the poet's ecocentric view. As such, the focus on outwards realities is magnified by the use of the most material dantismi and montalismi - especially those related to the landscape - as well as by borrowings from ecoregional anti-metaphysical authors such as Giorgio Orelli, Vittorio Sereni, or Giampiero Neri. Rewriting the outwards reality through trans-individual words and rhythms allows the poet to acknowledge and unveil the layers of stories inscribed in the matter, and as such to conceptualise reading as 'in itself an ecological activity'. ${ }^{39}$ Benzoni goes further down this path, arguing that a metaphysical tension is somehow retained in Pusterla's verse as a transitive legacy of Montale's voice. ${ }^{40}$ On the contrary, and in light of an ecopoetic perspective, I argue that Montale and other sources are used to overturn any metaphysical temptations in Pusterla's poetry, and that the author retains from their voices only what is at the core of his physical and eco-centric reflection: the matter, and the words and rhythms that most closely may approach and thus celebrate it.

\section{Translation}

A third element which I consider central in the development of Pusterla's ecopoetry is translation. Recent studies have relocated translation to the realm of translanguaging. ${ }^{41}$ The transformative power of both processes has been extensively investigated. In other studies, I have argued that the presence of open, fluid, and plural subjectivities in poetry can be related to dynamics of migration and translanguaging. ${ }^{42}$ When using a language beyond their mother tongue, authors are commonly faced with the need to learn how to rename objects, and they acquire novel sensual and linguistic tools with which to approach the outwards reality and to allow it to speak. Within this mobilisation of linguistic referents, landscapes and objects draw nearer. Translation, as an act of translanguaging, holds a similar potential to release language from superstructures and to indicate a path towards increased openness.

Pusterla has worked extensively as a literary translator, compiling amongst other things almost the entire corpus of Italian versions of the poetic works of the Swiss francophone author Philippe Jaccottet. ${ }^{43}$ Throughout a highly prolific poetic career, Jaccottet focused prominently on form and nature, pursuing a transparency of gaze and proposing the resizing of the poet's role to that of a simple convenor of sensual impressions. ${ }^{44}$ This is a path that many postmodern authors followed during the postwar period, especially within the francophone space. The contact with Jaccottet's nature poetry impacted enormously on the agglomeration of an ecocentric imagery in Pusterla, both on an imaginative and a linguistic level. Pusterla has on many occasions acknowledged this impact, and the implications of this dialogue have been comprehensively analysed. ${ }^{45}$ Moving beyond the specificity of this authorial

\footnotetext{
${ }^{39}$ Scott, 'Translating the nineteenth century', cit., p. 286.

40 Benzoni, 'Le smorfie del ghiaccio che si sgretola', cit., p. 83.

41 See M. Baynham \& T.K. Lee, Translation and translanguaging, New York, Routledge, 2019.

42 Note deleted to hide author's identity.

43 See M. Vischer, La traduction, du style vers la poétique: Philippe Jaccottet et Fabio Pusterla en dialogue, Paris, Éditions Kimé, 2009.

${ }^{44}$ See P. Jaccottet, La promenade sous les arbres, Lausanne, Mermod, 1957.

${ }^{45}$ F. Pusterla, 'Tradurre Jaccottet', in: Il nervo di Arnold. Saggi e note sulla poesia contemporanea, Milan, Marcos y Marcos, 2007, pp. 182-189.
} 
relationship, Pusterla has also expanded on the centrality of translation as a transformative intellectual process, and has explained how it enacted a veritable liberation of his poetic world:

Così l'idea del confine, dell'oltre, dell'altro da sé [...] appare più visibile attraverso la lingua; perché se la lingua che parlo e che penso è per me la misura del mondo, avventurarsi nelle parole e nei pensieri di un'altra lingua significa esplorare un altro mondo, guardare le cose con occhi diversi. ${ }^{46}$

This is a path that leads to an orientation towards the outward, and can be considered a further component of an ecocentric system. This connection is reinforced by Clive Scott's conceptualisation of translation as a process that is 'necessary to the deepening of the ecological experience of reading because it allows a modification of the text's landscape and weather, a deeper kinaesthetic involvement, a multiplication of types of linguistic and sensory contact'. ${ }^{47}$ We can thus argue that translation, an activity with which Pusterla engages in parallel to the unfolding of his own poetic trajectory, fosters and supports the development of an ecocentric mode within his verse, which is particularly visible from Bocksten on.

\section{The fossil-man: an analysis of Bocksten}

Bocksten is Pusterla's second poetry collection. It is inspired by the story of the Bockstensmannen, a medieval mummy discovered in 1936 in a peat bog in Sweden and who was found to have been murdered, beaten and pierced through the chest with three poles, possibly in a ritual assassination. The mummy surfaced from the bog in an incredibly well-preserved state, with a full head of red hair, clothes, shoes, and the three wooden rods that have killed him, so much so that the person who found the body believed it to be that of a recently murdered man. Pusterla saw the mummy in the Varberg County Museum shortly after the death of his father, and used the fossilman to articulate a reflection on life and death within a relational more-than-human environment, which marks an ecocentric turn in his poetics.

Pusterla's book holds a distinctive narrative and almost cinematic structure. It is made up of 56 movements organised into three sections of differing lengths, with the first and the third acting as a frame for the central one. ${ }^{48}$ Broadly, the book opens with a reflection on what remains after death (section 1), then dynamically expands on the liminal experience of the mummy (section 2), and finally closes with a more-thanhuman climax (section 3 ). The second section, eponymous with the collection, is the core of the book and the main focus of my analysis.

Scholars have pointed out a strong identification between form and nature in the collection. The movements of which it is composed, ranging in length from 3 to 26 lines, emerge from the page in a way that is similar to the surfacing of the more-thanhuman residues from the peat bog. White spaces hold an expressive and suspensive function. The play on densities, accelerations, and suspensions moulds the metre, which is organised around heterometric structures that are occasionally travelled by regular modules. ${ }^{49}$ Figuratively, the muffled landscape of the bog is agitated by flashbacks, illuminations, black-outs, and elements of tension that foreground a gruelling reconnection of human and matter, mediated by the mummy.

On the whole, the Bocksten man - as a fossil-man grounded in his material and chemical existence - is left with the pivotal tasks of revealing the ways in which

\footnotetext{
46 Pusterla, 'L'Inferno è non essere gli altri', cit., p. 27.

47 Scott, 'Translating the nineteenth century', cit., p. 291.

48 See Manetti, 'Il “libro del figlio"', cit., pp. 211-233.

49 Bocksten numbers 438 lines: $15 \%$ settenari; $25 \%$ endecasillabi.
} 
humans belong to a broader more-than-human history, and of recuperating a glimpse of hope in the interconnected ecologies that are progressively revealed. This process is textually realised through two main paths, a rhythmical one and a figurative one, which are briefly addressed below.

\section{Rhythm}

Following Meschonnic thought, herein I consider rhythm to be a comprehensive notion, transcending the mere linear development of accents, and including other aspects such as punctuation and the plastic and aural qualities of words and lines. ${ }^{50} \mathrm{As}$ is extensively recognised by scholars, the rhythm of Bocksten foregrounds a constitutive dialogic intention. The opportunities enacted by dialogism within the poetic discourse have been investigated in a number of analyses, all of which inform my reading. ${ }^{51}$ In Pusterla, dialogism is used primarily to mobilise and dismantle the central subject, and as such it embodies a trans-individual intention, which is in turn related to the poet's ecocentric vision.

The process by which voices are rhythmically pluralised is not a linear one. The various utterances that are at play in the collection are articulated over substantial and blurred zones of intersection. This characteristic points again to interconnectedness and contact as constitutive elements of the environmental system that the book proposes. The ensuing rhythmical taxonomy must therefore be conceived of not as a paradigm, but as an interpretative tool used to unveil dialogic trajectories on a micro-textual level, illuminating their innermost qualities.

On the whole, scholars have individuated two main utterances, mostly active in the book's main section, that have been read as embodiments of the author's and the mummy's voices respectively. These two voices frequently mingle, and they often merge with those of their interlocutors. As a consequence, they constantly oscillate between io and noi. This play on pronominal deixis contributes to the highlighting of their relationality.

The two voices tell Bocksten's story from different points of view, before then declaring their inseparability towards the end of the central section. This evolution is inscribed in their rhythmical unfolding. While the voices in fact follow rhythmical articulations that are already similar and move progressively closer as the work continues, some elements of distinctiveness can be observed. Here I provide some examples from the first voice in order of appearance, commonly identified as the authorial one:

Alcuni hanno scelto il mare, il suo rollio.

Altri coltivano segale, radici, e danzano la notte attorno ai fuochi.

lo scavo, scavo, non so perché. $(8,8-11)$

Chi sei? Che importa, sono, poiché sogni.

Allora si alzò il paesaggio, si mossero le nuvole.

Alberi e montagne vennero, deserti.

Iniziò il viaggio. (10)

Ti presterò una voce per il buio

una mano per $i$ tre pioli

nel tuo petto. (15)

50 See Meschonnic, Pour la poétique, cit.

${ }^{51}$ See V. Shemtov, 'Metrical hybridization: prosodic ambiguities as a form of social dialogue', In: Poetics Today, 22, 1 (2001), pp. 65-87. 
Le ho inseguite fin qui, renne, alci e martore, per incontrare te, temibile orso bianco, appuntamento che mi spiega tutto questo lungo viaggio tra paludi, baracche abbandonate, tracce, tende sfatte dalla bufera dell'inverno. Le ho seguite fin qui le loro orme solo per maledire le tue gengive rosse, e il tuo stupido sguardo, e i denti lunghi, e allora ti prometto: cercherò di non fuggire, di non gridare solo per paura. (50)

The excerpts above display the recurrence within this voice of a fast pace, verbs of movement, dry and sharp diction, and harsh sounds. On the whole, they demonstrate that this utterance is concerned with action: excavation (lo scavo, scavo 8), travelling (Iniziò il viaggio 10), advocacy (Ti prestero una voce per il buio 15), and pursuit (Le ho inseguite fin qui, renne, alci e martore 50). The mummy's story is approached by the authorial voice in response to the urgent need to formulate a hypothesis, and to approximate the enigma that is inscribed in the matter and in Bocksten's transindividual and trans-human body.

These rhythmical modes are close to (and sometimes intertwined with) those through which a fictional embodiment of the mummy's voice is articulated. The passages below record some instances in which this second utterance surfaces:

Eccomi qua nel buio

ed è lontano

il trotto dei cavalli, il passaggio

di corpi e luci e sagome sull'acqua.

Lontano il fuoco, le voci.

Eccomi nella torba.

0 forse dovrei dire

che io sono il lontano

trottare dei cavalli, io il passaggio

di umani nella neve, di barche traballanti sulle onde.

Ciò che resta del fuoco, delle voci.

Goccia nella caverna, muschio

sopra la roccia. Traccia, graffito,

immagine slavata. (19)

Mi portarono qui

con mille ragioni o per un disguido,

digrignando denti e recitando preghiere.

Vollero la certezza del non ritorno,

usarono pioli aguzzi e scongiuri,

e profonda melma.

Probabilmente urlai prima di cadere. (22)

Erano ali a sbattere fra i pini?

Ricordo solo un rovescio di sole, una luce spiovente,

e il silenzio boschivo, in attesa di passi.

E la certezza di quel cammino,

di quel pieno sentiero terroso,

e la tranquilla turbolenza del sangue.

Fossero pure ali: sprofondavo

in una terra morbida, fangosa. (23) 
Taccio da tanto tempo

che la terra è carbone,

la tomba muta in torba; se ora parlo

sei tu che m'inventi parlare,

ma se non sai

io non so cosa dire. (33)

Ma le ossa sono ossa, io sono io,

ieri non c'ero,

adesso eccomi qua. $(52,3-5)$

The examples demonstrate that the distinctiveness of this voice resides in a preference for fast-paced (often iambic) developments (Taccio da tanto tempo 33), a rhythmical insistence on the beginnings of lines (Ciò che resta del fuoco, delle voci 19, Erano ali a sbattere fra i pini? 23, la tomba muta in torba; se ora parlo 33), and a constitutive fluidity of expression, which emerges consistently. The latter is realised through a controlled use of musical-semantic components, such as consonant correspondences and, most crucially, proparoxytone inserts (eccomi, sagome, immagine 19, portarono, vollero, usarono 22, sbattere, fossero, morbida 23, eccomi 52). Fluidity has the function of rhythmically tracing the liminal human-geological experience of the mummy back to its chemical, transformative, and material composition. The proparoxytone movement of the fossil-man is circular, foregrounding the opening (eccomi 19) and closing (eccomi 52) of its discourse. The mummy is progressively configured as storied matter, to the point where it declares the need for its story to be uncovered and translated in order to be conveyed (sei tu che m'inventi parlare 33).

Both these utterances are traversed by a more decisive reflexive and environmental pulsation that intermittently takes the stage, sometimes permeating them and sometimes prevailing and erasing them. To this pulsation I attribute the full status of third and main voice in Bocksten and, following both Scott's and Lidström and Garrard's conceptualisation of the term, I define it as profoundly 'environmental'. ${ }^{52}$ This voice is in charge of carrying the essence of the collection's ecocentric message, by affirming the identification between language and nature. Below are some examples:

Nessuno riposerà alle betulle, accosterà la tua macchia.

Non è uno specchio ridente di ninfee

ma un pozzo fangoso il putridume che resta

di uno sconvolto passato. (17)

Bocksten, uomo di terra,

ossuto resto reso dal carbone,

dal groviglio dei secoli riemerso,

caso, muta protesta, accusa, vita

inchiavardata nel fango. (18)

L'acqua scende dal buio delle sorgenti, s'inoltra nella nebbia, trova il corso.

Stringono gli argini, i ponti:

l'acqua scorre

da scuro a scuro, tempo luccicante. (25) ${ }^{52}$ Scott, 'Translating the nineteenth century', cit., p. 286; Lidström \& Garrard, ““Images adequate to our
predicament”', cit., pp. 44-46. 
Sale su, aggalla in un risucchio lento,

il gorgo abbagliante che preme, si espande,

strascina un ricordo di caverna,

odore di muschio profondo,

dolore sordo, rimbombo

di tempi immutabili, eco di piombi,

catene, ferraglie,

è il mostro della stiva che sale sulla plancia,

l'urlo che nasce in pancia e vuole uscire. (37)

Oppure il buio è un imbuto

in fondo a un alambicco,

un cigolio di torchio da vinacce,

un sentimento stretto. (46)

As the excerpts show, this third voice is foregrounded by an increase in sintassi presentativa $(18,25,37)$, a sculptural attention to the line's components, an abundance of punctuation marks, a tendency to organise words in lists, a scarcity of verbs, and a constitutive preference for nominalisation. Onomatopoeic and mimetic effects are maximised (putridume 17, inchiavardata 18, luccicante 25, cigolio 46), whilst the verse adheres to and reproduces the flow of waters, the run of winds and rains, as well as the muffled environment of the peat bog, traversed by a catalogue of creatures such as martens, reindeer, moose, squirrels, ants, worms, and different kinds of micro-organisms, whose steps are rhythmically embodied by the verse.

This is also the voice that the poet imbues with the most hybrid and transformative elements of language, amongst which are parasynthetics (e.g. aggalla, 37, 1). The presence of these structures generates zones of intertextual relationality, which are realised through the processes of metabolisation and propagation individuated above. Parasynthetics - verbal forms coined from names and adjectives are particularly frequent in Dante's verse, and they are disseminated in Bocksten mostly as reinventions. From the most celebrated poet of the italophone tradition, Pusterla thus takes not only a civile inspiration, distinctively inflected in ecopoetic terms, but also, and perhaps most crucially, a faith in the fertile power of transformation, which surfaces in the form of morphological hybridity and is thus active within the smallest units of the verse. This process takes place on a sensual level, as a reappropriation of the material and explorative qualities of language, which the intertext supports and propagate.

On the whole, the environmental voice revolves around long paces, with notably frequent dactylic and anapaestic developments, recalling as such the movements of the chorus in classical literature. This feature is relevant, as it foregrounds a decided shift from the individual to the collective, from subjectivity to community. Progressively absorbing the other two utterances and configuring itself as a pulviscular pace, the environmental rhythm declares that all of Bocksten's matter belongs to a long period of progressive sedimentation and emersion. In the commonality amongst creatures, which is created through a dramatic de-humanisation and expansion of time, and through faith in the material qualities of language, Bocksten's ultimate appeal to resistance and liberation is eventually realised.

\section{Transitional imagery}

On a figurative level, relationality in Bocksten is conveyed through a predominance of transitional imagery; that is, through the recurrent embodiment of contacts and transformations, especially between human and non-human, but also between different elements and realms. The excerpts below display some examples: 
lontano muggiscono i treni, un bosco incombe $(5,5)$

Non è una mosca che ronza, sono fogli $(7,1)$

Il rosso dei capelli, guizzo di scoiattolo $(13,7)$

Sono il catrame, le materie oleose, sono l'acido acetico in potenza. $(39,1-2)$

il maltempo è solo tuo, tue depressioni, frane $(35,4-5)$

A quell'ora le correnti sono fili di ghiaccio, $(41,5)$

Oppure il buio è un imbuto, $(46,1)$

***

l'acqua si ferma in fossi, lascia fango $(4,2)$

Eccola qui, franosa nel suo estremo, volta al mare,

la terra. (9)

Allora si alzò il paesaggio, si mossero le nuvole. $(10,2)$

Le formiche salgono ordinate dai tubi $(12,1)$

sentieri additano il bosco $(16,1)$

lo dice l'acqua che scivola tranquilla $(26,1)$

The first set of excerpts engages with a series of metamorphoses that embody interchanges between different elements. Here the more-than-human, and in particular treni and bosco (5), mosca and fogli (7), and a scoiattolo (35) are called on to re-inhabit and re-invent anthropic imagery. Through these contacts, and especially through the metamorphic affinity to the matter which Bocksten himself declares (Sono il catrame, le materie oleose 39 ), the poetry 'relocates the human into the natural sphere, as a similar product of complex chemical processes'. ${ }^{53}$ The second set of lines transcribed above recalls a particular kind of transformation: personification, a foundational figure in Bocksten, which here embraces nuvole (10), formiche (12), sentieri (16), and, even more crucially, acqua $(4,26)$ and terra (9). Personification foregrounds the polyphonic architecture of the book up from the authorial choice to allow the mummy to speak. This specific use of the figure - otherwise considered controversial in ecocritical terms - reinforces the faith in the storied qualities of matter. As such, personification helps to translate and liberate the matter, qualifying as a dialogic opportunity and as a tool to illuminate commonality between beings.

On the whole, transitional imagery constitutes a further trajectory towards interconnection. Figuratively, it supports the mobilisation of hierarchies and facilitates a focus on aspects that are conventionally considered to be peripheral, enhancing the accumulation of relational imagery. Intertext is again appealed to in order to support this process. It is not by chance that L'anguilla del Reno, a poem which openly dialogues with Montale, is called on to almost seal this path, while at the same time proposing an impactful figuration of human and non-human animal bonding. This text

53 Ivi, p. 39. 
is a further witness to the pervasiveness and distinctiveness of Pusterla's use of intertext, because while it is true that many syntagms recall Montale's words directly, it is also true that they undergo a profound ecopoetic mutation in Pusterla. The way in which the eel is relieved of a correlative objective pointed towards the human, a feature that still permeates Montale's verse, corresponds to a novel desire for inclusivity and the capsizing of conventional power balances. The latter structures appear irrelevant in a time that is now common, relational, geological, and decidedly more-than-human. Poetic language, with its rhythmical and figurative qualities, supports and performs this ecocentric development.

\section{Conclusion}

This short excursus has expanded on how ecopoetic trajectories might constitute a productive framework with which to contextualise Fabio Pusterla's ecoregional verse. Pusterla belongs to a generation of poets who experienced, translocally, the effects of a profound environmental crisis. His work engages with a nature-centred and materialist stream active through centuries of literature, but maintains an ecocentric distinctiveness which is common in voices speaking from within the crisis. His ecocentric path orients itself towards constitutive receptivity, and the ability to employ a liberated environmental language, a process in which dynamics of intertextuality and translation play a central and mobilising role. At the core of this path is the faith in language as 'itself an ecology, an environmental medium, in which we achieve new forms of perceptual consciousness and experience'. ${ }^{54}$

A key collection in Pusterla's macro-textual path through receptivity, Bocksten configures itself as a point of connection between a conventional poetic mode, wherein a central subject is still present, and a relational one, wherein the subject is pluralised so as to reach a trans-individual level of expression. This trajectory is embodied in a diction that emerges and develops first of all through a relational communion with nature. This ability of poetry to rhythmically, figuratively, and transindividually embody outwards realities is perhaps the most crucial contribution that it can make to a rethinking of the world in an anti-anthropocentric direction, a task to which all disciplines are called on to contribute in a time of unprecedented crisis. Following this trajectory, the non-human can thus appear constitutively embedded in the human, and viceversa. They both may inhabit a space where difference is finally valued and hierarchies are erased, marking an overdue progression towards resistance and liberation.

\section{Keywords}

ecopoetry, versification, rhythm, style, translation

Alice Loda, University of Technology Sydney. Alice Loda is a Lecturer in International Studies and Global Societies at the Faculty of Arts and Social Sciences, University of Technology Sydney. Her research interests include modern and contemporary poetry, rhythm, translingualism, translation, migration, and ecocriticism.

University of Technology Sydney

Faculty of Arts and Social Sciences

PO Box 123 Broadway

NSW 2007 (Australia)

alice.loda@uts.edu.au

${ }^{54}$ Scott, 'Translating the nineteenth century', cit., p. 286. 
RIASSUNTO

\section{Eco-Pusterla}

\section{Un'analisi semantico-stilistica di Bocksten}

La relazione tra uomo e ambiente rappresenta uno snodo fondamentale nello scenario contemporaneo. Il discorso sull'ambiente è stato articolato in diverse discipline e rappresenta un punto cruciale di molte agende accademiche, politiche e militanti.In questo articolo propongo una riflessione su come la poesia, nelle sue qualità di linguaggio ritmico ed immaginativo, possa supportare una visione fluida e non gerarchica del mondo e contribuire una riconcentualizzazione anti-antropocentrica della relazione fra umano e non-umano. L'articolo riflette su questi temi attraverso un esame del percorso poetico dell'autore Svizzero italofono Fabio Pusterla e della sua raccolta Bocksten, apparsa in prima edizione nel 1989 e ripubblicata senza sostanziali varianti nel 2003.

In una prima parte, teorica, il contributo si concentra sul concetto di ecopoesia e si addentra nell'esame di tre nozioni che nutrono la riflessione ecocentrica di Pusterla, cioè ricettività, intertestualità, traduzione. In una seconda parte, propone una lettura delle dinamiche ecopoetiche attive nella tessitura testuale di Bocksten, soprattutto a livello ritmico e figurativo. Complessivamente, questo lavoro si propone di dialogare con gli studi che discutono il processo di radicalizzazione delle poetiche contemporanee in direzione ecologica e relazionale, e si muove pertanto anche al di fuori della tradizione italofona, nel tentativo di riconoscere le caratteristiche di un movimento translocale basato su contatto e interconnessione. 